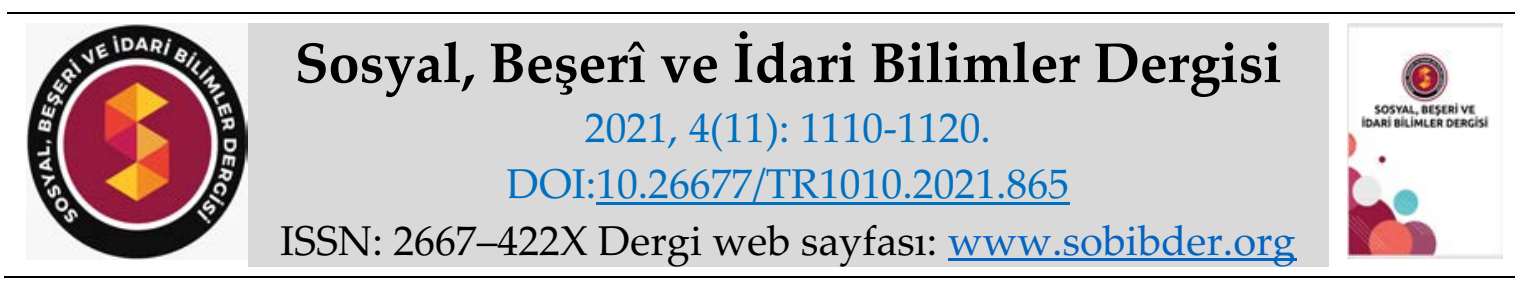

KAVRAMSAL MAKALE

\title{
Yapay Zekânın Yönetici Verimliliğini Artırma Potansiyeli Üzerine Bir Değerlendirme
}

Dr. Öğr. Üyesi Mesut ATASEVER, Uşak Üniversitesi, Uygulamalı Bilimler Fakültesi, Uşak, eposta: mesut.atasever@usak.edu.tr ORCID: https://orcid.org/0000-0002-7189-7551

Öz

Dijitalleşme ile birlikte hemen her türlü iş ve üretimin teknoloji ile bağlantılı hale gelmesinin önemli sonuçlarından olan yapay zekâ kavramı yönetim ile de yakından ilişkilendirilmektedir. Mal ve hizmet üretiminin gittikçe arttı̆̆ 1 ve karmaşık hale geldiği iş dünyasında yöneticilerin yükleri ve zorlukları da her geçen gün artmaktadır. Artan, karmaşıklaşan iş dünyasında yöneticinin işlerini kolaylaştırmak, verimliliğini arttırmak, zaman kazanmasını sağlamak ve gereksiz işlerle uğraşmasını önlemek oldukça önemlidir. Bu çalışmanın amacı yapay zekâ kavramının halihazırda gelişme döneminde ve gelecekte olgunluk döneminde yöneticinin ve yönetimin verimliliğine ne düzeyde katkı yapabileceğine ve bunun yanında olumsuz etkileri olup olmayacağına dair bir değerlendirme yapmaktır. Amaca yönelik olarak derleme, yorumlama ve tartışma yöntemi izlenmiştir. Bu çalışmada kapsam olarak mal ve hizmet üreten işletme yöneticiliği ve yapay zekânın şimdiye kadarki gelişiminden geleceğe dair bu alandaki potansiyeli ele alınmıştır. Yapay zekânın her düzeydeki işletme yöneticisinin görevlerini birçok bakımdan kolaylaştıracağı, bazı konularda yöneticiyi gereksiz kılacağı ve fakat bunun yanında yöneticiliğin ve yönetilenlerin insan olmaları, yapay zekânın ise ne kadar gelişirse gelişsin bir makine olduğu gerçeği, olası olumsuz etkisi olarak göz ardı edilemez. Bu çalışmanın yönetim, örgütsel davranış, insan kaynakları yönetimi ve organizasyon konusunda, sektörel ve akademik olarak yararlı olması beklenmektedir.

Anahtar Kelimeler: Yönetim, Verimlilik, Yapay Zeka.

Makale Gönderme Tarihi: 24.08.2021

Makale Kabul Tarihi: 02.11.2021

\section{Önerilen Atıf:}

Atasever, M. (2021). Yapay Zekânın Yönetici Verimliliğini Artırma Potansiyeli Üzerine Bir Değerlendirme, Sosyal, Beşeri ve İdari Bilimler Dergisi, 4(11): 1110-1120. 


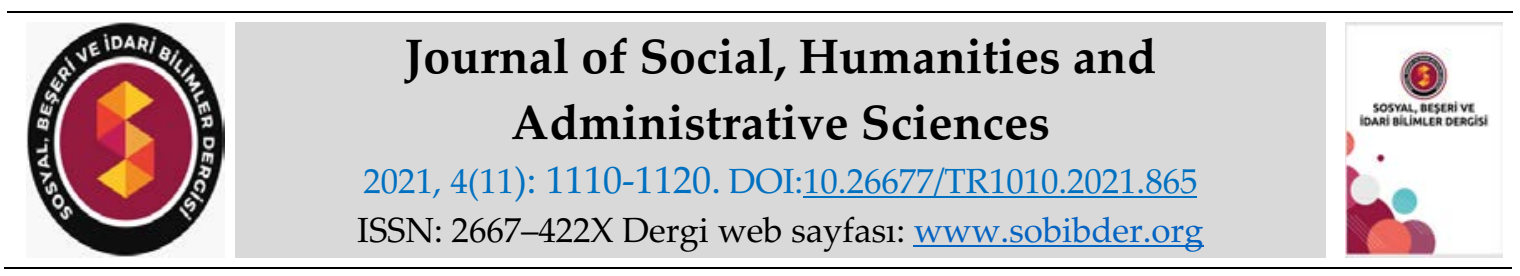

\title{
CONCEPTUAL PAPER
}

\section{Evaluation of Artificial Intelligence Increasing Potential for Business Management}

Assistant Prof. Dr. Mesut ATASEVER, Uşak University, Faculty of Applied Sciences, Uşak, email: mesut.atasever@usak.edu.tr ORCID: https://orcid.org/0000-0002-7189-7551

\begin{abstract}
The concept of artificial intelligence, which is one of the important results of the connection of almost all kinds of business and production with technology, is also closely associated with management. In the business world, where the production of goods and services is increasing and becoming more complex, the burdens and difficulties of managers are increasing day by day. In an increasing and complex business world, it is very important to facilitate the work of the manager, to increase his efficiency, to save time and to prevent unnecessary work. The aim of this study is to make an assessment of the extent to which the concept of artificial intelligence can contribute to the productivity of the manager and the management in the current period of development and in the maturity period in the future, as well as whether it will have negative effects. For the purpose, the method of compilation, interpretation and discussion was followed. In this study, business management that produces goods and services and the potential of artificial intelligence in this field for the future are discussed. The fact that artificial intelligence will facilitate the tasks of business managers at all levels in many ways, make the manager unnecessary in some matters, but besides, the fact that the manager and the managed are human, and the fact that artificial intelligence is a machine no matter how much it develops cannot be ignored as a possible negative effect. It is expected that this study will be beneficial in terms of management, organizational behavior, human resources management and organization, both industrially and academically.
\end{abstract}

Keywords: Business Management, Productivity, Artificial Intelligence.

Received: 24.08 .2021

Accepted: 02.11.2021

\section{Suggested Citation:}

Atasever, M. (2021). Evaluation of Artificial Intelligence Increasing Potential for Business Management, Journal of Social, Humanities and Administrative Sciences, 4(11): 1110-1120. 


\section{Gíriş}

Teknolojinin yönetim işlerini kolaylaştırdığı bir gerçektir. Bundan farklı olarak yöneticinin sorumluluğunda olan işlerin kolaylaşması, özetlenmesi, somutlaştırılıp şemalar halinde sunulması gibi konularda yapay zekâdan yararlanması yakın ve orta gelecekte bu alanda önemli gelişmeler yaşanmasını tetiklemesi beklenmektedir.

Yapay zekânın sıfırdan herhangi bir değer ortaya koyması değil, var olan ve verilen verilerden hareketle yeni çıkarımlarda bulunması beklenmektedir.

Yöneticinin bilgi elde etme, bilgilerden yararlanma ve karar alma konusunda yapay zekânın zaman kazandıracağı, doğru kararlar alma yönünde değer katacağı görülmektedir.

Tüm yönetim işlevlerinin daha hızlı gerçekleşeceği, bununla birlikte yöneticiye farklı görevler ve sorumluluklar ekleneceği de görülmektedir.

Tek bir model yapay zekânın bütün işletme düzeylerinde ve her büyüklükte işletmede aynı zamanda her sektörde işe yaramasını beklemek mümkün görünmemektedir. Bundan dolayı işletme yöneticiliğinde yapay zekânın faydalı olabilmesi ve yöneticiye etkinliğini ve verimliliğini arttırabilmesi için yöneticinin sorumluluğunda olan işletmenin büyüklüğü, sektörü yapılan iş işlerin analizi, işlerin tanımı, güçlü yönler zayıf yönler, paydaşlarla ilişkiler, finansal durum ve yöneticinin ilgilenmesi gereken konularda temel verilerin girilmesi ve tüm bu temel verilerin birbirleriyle olan ilişkilerinin sisteme verilmesi, ideal değerlerin ve gerçekleşen değerlerin tüm bilgilerini nasıl yorumlanması gerektiği baştan verilmelidir. Yapay zekâ tüm bunları içerecek ve kendini geliştirecek şekilde yapılandırılmalıdır. Bu yüzden, yapay zekânın veriye dayalı hareket ederek kendisini geliştirebileceği düşünüldügünde, iyi bir yapay zekâ planlaması ve yapılandırılması, başarılı bir yönetim destek sistemï için kaçınılmazdır.

Göz ardı edilmemesi gereken önemli bir konu var ki, işletme ve işletmenin yönetimi hiçbir şekilde insandan bağımsız düşünülemeyeceği için, insana ait temel unsur olan duygular ve yapay zekâ ilişkisi nasıl olacaktır? Bu konu gelecekte yapay zekânın açmazlarından ve bu alanda çalışanların uğraşlarından biri olacaktır.

Çalışma, yapay zekâ ve gelişimi, yönetici ve verimlilik, yapay zekânın yönetici verimliliğini artırma durumu başlıkları ile ele alınmıştır. Sonuç ve değerlendirme bölümünde olası olumlu ve olumsuz etkiler tartışılmış ve yorumlanmıştır.

\section{YAPAY ZEKÂ KAVRAMI ve GELIŞ̧IMI}

Yapay zekâ kavramı, terim olarak ilk defa 1956 yılında "Dartmouth Çalıştayı'nda" John McCarthy tarafından gündeme getirilmiştir (Gülşen, 2019: 410). Tanımlamak gerekirse yapay zekâ insan zekâsının sinir sistemi, gen yapısı gibi fizyolojik ve nörolojik yapısının ve doğal olayların modellenerek makinelere aktarılmasıdır (Pomerol, 1997: 4). Alan olarak yapay zekâ, disiplinler arası bir bilim alanıdır. Yapay zekâ alanını oluşturan disiplinler arasında mantık, istatistik, bilişsel psikoloji, karar teorisi, sinirbilim, dilbilimi, sibernetik ve bilgisayar mühendisliği gibi disiplinler vardır (Howard, 2019: 918).

Yapay zekâ kavramı henüz gelişme aşamasında olan, sonu ve sınırları henüz belirginleşmemiş olan bir kavramdır. Sağlık alanında, devlette, sosyoloji ve psikolojide, bilimsel araştırmalarda ve çok faktörlü tahmin gerektiren her alanda başarılı olabilecek henüz olgunlaşma aşamasında gelmemiş, gelecek vaat eden bir enstrümandır.

Endüstri 4.0 ile ilgili gelişmelerin katkısı ile birlikte robotların fiziksel iş yükünün, yapay zekanın ise zihinsel iş yükünün yerini alacağı çalışma ortamlarının, ergonomi ve insan faktörleri 
uygulamaları için yeni alanların önünü açtığı görülmektedir. Endüstri 4.0 ile yaygınlaşan otomasyon, fiziksel olarak zorlayıcı işlerde ergonomik iyileştirmeler yaparak çalışanların olası sağlık problemlerini minimize edebileceği öngörülmektedir. (Çakıt vd., 2020).

Yapay zeka, mevcut sorunun tanımı bilinir, fakat çözüm yöntemi bilinmezken, doğru ve verimli bir çözüm yöntemini öğrenen, ya da keşfeden, insan eliyle üretilmiş sistemlerin tümüne verilen isimdir. Kısaca yapay zeka, algoritma üretebilen otomatik sistemlerdir (Köroğlu, 2017).

Bununla birlikte yapay zekadan beklentilerin her iki yönde de abartılı olmaması gerektiği düşünülmektedir. Yapay zeka halihazırda geçerli olan teknolojiden çok daha fazla potansiyeli olan bir kavram olarak görünmektedir. Fakat insandan bağımsız bir kavram olmadığı için ve tüm birikimlerini insanla beraber geliştirebileceğinden tüm işletme ve yönetim sorunlarına kısa ve orta vadede çözüm olabilecek bir kavram da değildir.

Yapay zekânın yakın gelecekte işletmelerde yaşamsal öneme sahip bir rekabet aracı olacağı, iş alanlarında ve içeriklerinde, yönetim tarzında, örgüt yapısında ve kültüründe sarsıcı değişikliklere sebebiyet vereceği beklenen bir durumdur. Bu sebeple, işletme alanında yapay zekâ uygulamaları, yapay zekâ edinimi ve gelecekte ortaya çıkabilecek potansiyel etkilerini inceleyen araştırmalara olan ihtiyaç gittikçe artmaktadır (Ünal ve Kılınç, 2020).

Yapay zeka veri ile çalışan, hareket eden ve kendini geliştiren bir teknoloji olduğu için öncelikle neyin iyi neyin kötü olabileceğinden, neyin olması neyin olmaması gerektiğine, neyin amaçlandığına kadar bir işletmedeki tüm ayrıntıların veri olarak girilmesi gerekir. Daha sonra koşullar, durumlar, rakamlar değiştikçe yapay zekanın bunlardan öğrenebilir hale gelmesi, var olandan yeni çıarımlar yapabilmesi, zaman zaman öğrendiklerinin onaylanması gerekecektir. Bu durum için öncelikle bu işe özel personelin bu iş özelinde yoğun olarak ve uzun süre çalışması gerekebilecektir. Daha sonra yapay zekanın getirileri belirginleşmeye başlayabilir. Ayrıca kısa ve orta vadede yapay zekadan büyük beklentiler içinde olmak hayal kırıklığı yaratabilecektir.

Yapay zeka ile birlikte hukuki ve cezai sorunlar da gündeme gelmeye başlamıştır (Köken, 2021). Yapay zekanın suç işleme potansiyeli olmasına rağmen insan olmaması nedeniyle cezai sorumluluğu söz konusu olmayacaktır (Sarı, 2020).

Teknolojinin, özelde de yapay zekanın her zaman fayda getirebilecek bir kavram olduğunun düşünülmemesi gerekir.

Dünyadaki bütün bilimsel gelişmeler, direk olarak insanlığı yok edemeseler de bu potansiyeli doğurabilecek başka gelişmelere zemin hazırlayabilirler. Bu zemin de ancak insan eliyle tehlikeli hale getirilebilir. Bunun dışında yapay zekânın bir tehlikesinden bahsedilemez. Yani yapay zeka insandan bağımsız insanlığa zarar veremez (Köroğlu, 2017). Öztürk, (2019)'a göre bununla birlikte yapay zekânın insan hayatında yer edinmesi günümüzde düşünme ve iş becerilerini kısıtlayacak, gelecekte ise insan ırkı için sorun yaratabileceği düşüncesi ile yapay zekânın etik konularına ihtiyacı vardır.

\section{YÖNETICILIIK ve VERIMLILIIK}

Birden fazla kişinin birlikte bir iş başarma durumu söz konusu olduğunda yönetim kavramı ve yönetimi gerçekleştiren yönetici kavramı devreye girmektedir. İşletmelerde, derneklerde, askeriyede ve kamuda farklı kademelerde yönetim işlerin yürütülmesinden sorumludur. Çalışma özelinde işletme yönetimi açısından, yöneticilerin işleri yürütürken karşılaştıkları çok sayıda farklı kategorilerde zorluklar mevcuttur. Yönetimin fonksiyonları olan, planlama, örgütleme, yöneltme, denetim ve tüm bu fonksiyonları uyumlandıran koordinasyon kavramı, yöneticiye iş akışını ve düzenini kolaylaştırır. Ayrıca bunlarla birlikte, yöneticinin önem 
düzeyleri farklı olmakla birlikte başka işleri de her zaman gündemdedir. Karar alma, insan ilişkileri, problem çözme, motive etme, etik davranma ve davrandırma, mümkün olduğu kadar demokratik liderlik etme, çalışanların işlerinden tatmin olmasına yardımcı olma gibi işler tüm düzeylerde yöneticinin günlük işleri arasında yer alır.

Bu işlerin başarısı, yöneticinin düzey, yetenek ve kapasitesi, ilgili sektör, yapılan işin niteliği, kültürel ve coğrafi çevre, teknolojiye hakimiyet gibi birçok faktöre bağlıdır.

Verimlilik kavramı, yöneticinin gösterdiği çabanın ne düzeyde başarıya yansıdığı ile ilgili olup oldukça önemlidir. Verimlilik tanımlanırken çoğunlukla mal üreten işletmeler üzerinden tanımlanmıştır. Çıktıların girdilere oranının yüksek olması genel kabul görmüş bir tanım olarak görünmektedir. Burada bir ayrıma gidilecek olursa, işletmenin başarısı çalışanların verimliliği ile, çalışanların verimliliği ise yöneticinin verimliliği ile artmaktadır. Mal veya hizmet üretirken girdilerden daha fazla çıktı elde etmek amaç edinilmektedir. Yönetici açısından ise tüm çabaları girdi olarak, bu çabaların maddi ve maddi olmayan sonuçları ise çıktı olarak ele alınmaktadır.

Etkinlik, etkililik ve verimlilik işletmelerin teknik performans göstergeleri arasında yer almaktadır. Teknik performans göstergeleri performansın tüm boyutlarılla ölçülmesine olanak tanımaktadır. Teknik göstergeler, faaliyetlerin, üretim faktörlerinin, çalışanların performansının ölçümünde kullanılmaktadır (Yükçü ve Atağan, 2009).

İnsan olarak her yöneticinin genel ve özel sınırları kapasitesini belirlemektedir. Yöneticinin kapasite ile ilgili alanları uzun bir liste haline getirilebilir ve listenin her konusu ayrı ayrı geliştirilmeye uygun olacaktır.

Örgütlerde var olan kaynakların verimli bir biçimde değerlendirilmesinden sorumlu kişiler olan örgüt yöneticilerinin, başarılı olabilmek için kıt kaynakları ve dolayısıyla ikamesi olmayan zaman kaynağını verimli kullanması gerekir (Karaoğlan, 2006).

Yine verimlilik, üretim sistemleri açısından genel olarak üretim faktörlerinin etkin bir şekilde kullanımı olarak ifade edilmektedir. Üretim faktörlerinin etkin kullanımı; üretimin gerçekleşebilmesi için gerekli insan, makine ve malzeme gibi temel kaynakların işletme hedeflerinin yakalanmasında israf edilmeden tüketilmesini ve meydana gelecek ürünün istenilen zaman, miktar, kalite ve mümkün olan en düşük maliyette ortaya çıkarılmasını ifade eder (Kayar, 2012).

Fakat verimlilik kavram genişlemesine uğramış ve fiziksel çıktılar yanında nitel ve zihinsel çıktılarla da ilgili kullanılmaya başlamıştır.

Yöneticinin dikkatinin, algılarının, detaycılığının, denetim kapasitesinin, rakamlarla olan işleri çözümlemesinin, çalışanlarla olan ilişkilerinin ne düzeyde sağlıklı olduğunun, iletişim yeterliliğinin, yapılan işin teknik gereklilik ve detaylarının anlaşılmasının sınırları ve geliştirilebilirliği mevcuttur. Tüm yöneticiler açısından gelişmeye ve geliştirmeye ihtiyaç duymayan bir alan yoktur. Bir diğer yönden yönetici, uyuyan, yorulan, dikkati dağılan, üzülen, mutlu ve mutsuz olan, sakin olan, sinirlenen, depresif davranabilen bir insandır. Fakat örgüt, işletme, kurum daha nötr olması gereken, objektif ve kurumsal davranması gereken tüzel bir kişiliktir. Bu açıdan da yönetim ve yöneticinin geliştirilmeye açık alanları mevcuttur. Yöneticinin verimliliğe ihtiyacı yadsınamaz ve bu bakımdan hep bir verimlilik arayışı olmuştur.

Bir de yöneticiler başarılı ve başarısız yöneticiler ayrıma tutulduğunda, başarılı yöneticilerin verimliliğe ihtiyaçları olmadığı gibi bir algı yanlıştır. Çünkü genel kanı, bir yöneticinin ne kadar başarılı olabileceğini cam bir tavan olarak belli bir düzeyde tutmaktadır. Bu cam tavanı kırabilecek bir olgunun var olabileceği, günümüzde teknoloji ve yapay zekâ ile mümkün hale gelebilecektir. 


\section{YAPAY ZEKÂNIN YÖNETİCI VERIMLİLIĞİNİ ARTIRMA DURUM}

Bir yöneticinin görevlerini yaptığ 1 işleri listelendirmek kolay değildir. İnsanla ve işletme ile ilgili tüm konularda yöneticinin ilişkisi ve çalışması mevcuttur. Liste yapılsa bu listede binlerce madde bulunabilirdi. Bu çalışmanın kapsamı ve sınıllılıkları içinde kalmak üzere birkaç örnek verimlilik potansiyeli üzerinde durulmuştur. Potansiyel verimlilik artması beklenen alanlar, yapay zekanın şimdiye kadarki kullanım alanlarından ve TCCB Ulusal Yapay Zekâ Stratejisi 2021-2025 kitabından elde edilen çıkarımlarla belirlenmiştir (https://cbddo.gov.tr).

\section{Karar Alma}

Bir yöneticinin en önemli görevlerinden birisi karar almadır. Çünkü karar almada birçok değişken ve parametre göz önünde bulundurularak işletme açısından en uygun ve karlı olan karar belirlenmektedir.

Parametreler, değişkenler ve tüm bunların ayrıntıları ile birlikte, geçmişte şu anda ve gelecekte nasıl değişikliklere uğradıkları ya da değişebilecekleri mutlaka göz önünde bulundurulmalıdır. Kabul edilmelidir ki yönetici bir insandır ve sınırları vardır. Çoğu zaman aslında mümkün olabilecek analizler sentezler çıkarımlar sadece insan sınırlarından dolayı dikkate alınmayabilmektedir ya da öngörülemeyebilmektedir. Yapay zekâ bu soruna bir çözüm olabilecektir. Karar alma genellikle en sonunda tek başına yapılan bir işlevdir fakat onun öncesinde uzun yorucu toplantılar, birçok sunumlar bilgiler karmaşası mevcuttur. Yapay zekâ toplantıları daha kısa daha net hale getirebilecektir. Bir açıdan yöneticiliği daha teknik bir meslek haline getirmesi gibi bir durum söz konusudur.

\section{Zaman Yönetimi}

Yöneticinin en kıymetli değerlerinden birisi zamandır. Gerekli veya gereksiz birçok konu yöneticinin zamanını boşa harcanmasına neden olur. Yapay zekâ boşa harcanan zamanı minimuma indirebilir ve artan zamanda daha verimli işler mümkün hale gelir.

Özellikle bilgi toplama, bilgiyi analiz etme, sadece yararlı bilgileri bulma, özetleme yöneticiye fazlasıyla zaman kazandıracaktır. Günümüz teknolojisiyle bir yöneticinin günlerini alacak bir bilgi edinme durumu yapay zekâyla saniyeler içinde elde edilebilecektir. Bir örnekle somut hale getirilecek olursa, büyük bir işletmede çalışanlardan takım oluşturulması gerektiğinde tek tek çalışanların dosyaları incelenerek kabiliyetlerine öğrenimlerine becerilerine bakmak gerekebilir. Fakat yapay zekâ tüm dosyalardaki bilgilere ulaştıktan başka hâlihazırdaki durumlarına psikolojilerine motivasyonlarına da bakarak en uygun takım önerisini yöneticinin önüne getirebilir. Bu da yöneticiye tahmin edilenden daha fazla zaman kazandırabilecektir.

\section{Bilgi Edinme}

Yöneticinin sadece işletme ile ilgili değil işletmenin yakın uzak ve küresel çevresi ile de ilgili bilgiye sürekli ihtiyacı olacaktır. Bu bilgiler bazen düz bilgi olabileceği gibi daha kompleks bilgi ihtiyacı da olabilir. Bunun dışında bilgileri elde etme, elde edilen bilgileri kategorize etme, listelendirme, somut hale getirme, şemalandırma özetleme en önemlisi de yorumlama işleminin yapay zekâ tarafından yerine getirilmesi bilgi edinme işini zorluk olmaktan çıkararak bir avantaja dönüştürebilecektir. 
Çoğu zaman bilginin tamamı değil, özeti, sonucu, şema ve grafik haline getirilmiş durumu işe yaramakta olduğundan bu bakımdan da yapay zekâ yöneticiye destek olacaktır.

İyi yapılandırılmış bir yapay zekâ yönetim destek sistemi kademe ve sayı olarak yöneticileri de sadeleştirip azaltacaktır.

\section{Denetim}

Denetim, genel anlamıyla planlanan ile gerçekleşenin karşılaştırılması, daha sonra gerçekleşenlerde görülen eksiklik fazlalık farklılık varsa nedenleri üzerinde durulması, feedback verilmesi, planlamaya ve üretime dönüp tekrar bakılması, düzeltilmesi gereken yerlerin yeniden düzeltilmesi, biçiminde bir döngüyü ifade etmektedir.

Yapay zeka, zaten planlama öncesi aşamadan başlayarak planlama da dahil sürecin tamamını bir insana yakın mantık bütünlügünde ele alarak tüm üretim ve süreci takip edeceği için, anlık denetim denilebilecek bir denetim biçimini yürütür, bir insanın sınırlarında gerçekleşmeyecek biçimde detaylı ve nokta atış düzeltmeler önerir, olabilecek minimal hataları gerçekleşen minimal hataları da dahil yöneticilerin, ilgililerin önüne getirir ve eğer gelişmiş bir yapay zekadan bahsediliyorsa, yöneticinin önüne getirilmeden önce birçoğunu çözer, sadece karar verilmesi gerekenler konusunda yöneticiye ulaşır, çözüm ve düzeltmeler için karar seçeneklerini de tepe yöneticisine ulaştırır. Her karar seçeneğinin avantaj ve dezavantajlarını da liste haline getirir.

Yönetimin fonksiyonlarından olan denetim konusunda da yapay zeka yöneticiye büyük kolaylıklar sağlar, zaman kazandırır, gereksiz meşguliyetleri önler gözden kaçabilecek olan her şeyin göz önünde olmasını sağlar.

\section{İnsan Kaynakları Yönetimi}

İnsan kaynakları yöneticileri; personel ve iş süreci ile ilgili doğru verilerin toplanması, personel eğitim ve işe alımı, oryantasyon süreci ve performans değerlendirmesi gibi zor işlevleri kolaylaştırmak için yapay zekâ teknolojilerini kullanmaktadırlar (Gür vd., 2019).

Personel yönetiminden insan kaynaklarına geçişten itibaren bir işletmede en önemli kaynağın insan olduğu reddedilemez bir gerçek haline gelmiştir. Bir makinenin çalışanların motivasyonunu iş tatminini mutluluğu nu depresyonunu tespit etmesi çelişki gibi görülebilmektedir. Gerçekten de bu kompleks ve tartışılabilir bir durumdur. Fakat yapay zekayı programlayıp yönlendirecek olanın ve son kararı verecek olanın yine insan olduğu düşünüldügünde çok da yadırganacak bir durum söz konusu olmayacaktır.

Yapay zekâ desteği olmayan bir yönetici ile yapay zekâ desteğine sahip bir yönetici arasında oldukça büyük farklar olabilecektir. Bir insanın gözlemlemesi çok zor olabilecek iş başarımları, motivasyon eksiklikleri, iş tatmini durumları, kaytarma, sanal kaytarma, örgütsel bağlllık durumları gibi psikolojik durumlardan, günlük, aylık, yıllık, çalışan döngüsü, iş kaybı gibi durumlara kadar net şemalar sunumlar yönetici için oluşturulabilir. Yine birçok konu yönetici müdahalesi gerektirmeden yapay zekâ tarafından çözülecektir.

\section{Problem Çözme}

Problem çözme bir yöneticinin asli işleri arasında yer almaktadır. Aslında yöneticinin çoğu zamanı küçük veya büyük problem çözmekle geçer. Problemi tespit etme, çözülebilirliğini analiz 
etme, seçenekleri belirleme, seçenekler arasından en uygun çözümü bulma, çözüm için gerekenleri uygulama, yöneticinin gerçekleştirdiği işlerdendir.

Yapay zekâ ile birlikte birçok problemin ortaya çıkma aşamasında çözüleceğini ve ortaya çıkan problemlerin, tüm analizinin yapılmış olarak ve seçenek verileri ortaya konularak yöneticinin önüne geleceği belirtilebilir.

Yapay zekaya aslında öğrenen örgütün teknolojik hale getirilmiş biçimidir denilebilir. Nasıl ki insan ve örgüt zamanla öğreniyor ve öğrendiklerinden yeni çıkarımlar yapabiliyorsa yapay zekâ da zamanla deneyimlerle öğrenerek mükemmel hale gelerek daha az problem yöneticinin önüne gelecektir.

\section{Duygular}

Yapay zekâ işin içine hiç girmediğinde bile insanların duyguları ve bu duyguların davranışlara yansıması, duyguların çalışma hayatını olumlu ve olumsuz etkilemesi durumu, oldukça zor ve karmaşık bir konudur. Duygular insanı insan olarak tanımlayabilmek için en önemli faktörlerden birisidir. İnsanlar sadece akıl ve bilgi ile değil bunun yanında duygularıyla da hareket ederler. Birçok duygu iş hayatını olumlu etkileyebilirken bazı duygular ise iş hayatında olumsuz etkiler bırakabilir. Bu durum hem yöneticiler hem de çalışanlar açısından ortaktır.

Sevgi, sayg1, iş tatmini, üzüntü, korku, endişe, öfke, kin, minnettarlık ve şükran duygusu utanma, pişmanlık, özgüven, kararsızlık, yılgınlık, depresyon, mutluluk insanların davranışlarını etkileyen duygulara örnek olarak verilebilir.

Elbette yapay zekâ tahminlerin çok üstünde bir gelişim düzeyine ulaştı̆̆ında insanlardaki bu duyguları duyguların altındaki sebepleri duyguların etkilerini ve davranışlara yansımasını kolayca belirleyip çözümlerini de ortaya koyabilecektir. Fakat yakın ve orta gelecekte bu mümkün görünmemek ile birlikte uzun vadede, yüz tanıma, davranış analizi, nöro-algılama gibi çalışmalar ile davranışları tanımak, bu davranışlar ile ilgili yönetsel olarak neler yapılabileceğini önermek ve gerekirse uygulama yapmak yapay zekânın mümkün kıldığı durumlar olacaktır.

Teknoloji, yakında yapay zekanın sadece yöneticileri desteklemekle kalmayıp onların yerini almasını da sağlayacaktır. Bu sebeple bir diğer soru, bu tür bir yerini almanın yasal olarak kabul edilebilir olup olmadığıdır (Möslein, 2021). Bununla birlikte farklı etik tartışmaların da gündeme geleceği akıldan çıkarılmamalıdır. Çalışanların duygularını anlayabilmek, davranışlarından çıkarımlar yapmak, kişisel alana bir müdahale midir? izin alınmalı mıdır? izin alınmalı ise çalışanlar ve yöneticiler buna izin verecekler midir? bunlar hep gündemde kalacak etik sorulardır.

\section{SONUÇ ve DEĞERLENDİRME}

Yapay zekanın kısa vadede yönetici verimliliğini arttırması beklentisi abartılı olabilir. Çünkü yapay zeka üretilip yazılım üzerinde çalışlıp hemen kullanılır hale gelecek bir kavram değildir. Deneyimlerle bir insan gibi kendini geliştirecek bir oluşumdur. Dolayısıyla ya her işletme için tek tek büyüyüp gelişecek en sonunda işe yarar hale gelecektir ya da bir süre sonra birçok deneyimden elde edilen gelişmiş yazılımlar yaygınlaştığı anda işletmeler bu yazılımı elde edip yöneticiye destek olarak kullanacaklardır.

Desteğe ve verimliliğin artırılmasına ihtiyaç duymayan bir işletme ve yönetim birimi olamaz. En başarılı yöneticilerin eksik kaldığı noktalar, zaman yetiremediği durumlar mevcuttur. 
Dolayısıyla bu ihtiyaç hiçbir zaman bitmeyecektir. Söyle de söylenebilir, en gelişmiş yapay zeka kendini tamamladığında bile artık bu tamam daha ilerisi yok denilemez.

Birçok iş yöneticinin zamanını gereksiz yere meşgul eder ve uzun vadede geliştirilecek olan yapay zeka yöneticinin önüne gelen işlerin önemli bir bölümünü daha gelmeden çözerek yöneticiye düşen işler azalacaktır. Bu bakımdan yapay zeka zaman yönetimi konusunda yöneticinin verimliliğini artıracaktır.

İnsan kaynakları konusunda ise teknik bakımdan büyük yararları olabilecektir. Motivasyon eksikliği ve çözüm önerileri, olumsuz çalışan döngüsü nedenleri ve çözümü, çalışanlarla ilgili bürokratik işler yapay zekanın kendiliğinden çözebileceği ve yerine getirebileceği işler olabilir

Yapay zeka yine problem çözümünde de yöneticinin işlerini azaltıp kolaylaştıracak bir etken olacaktır. Çünkü önceki deneyimlerden hareketle daha önce çözülmüş bir problemi başka problemlerle eşleştirip daha yöneticinin önüne gelmeden çözmüş olacaktır ya da kendisi çözmeye karar vermeden önce seçenekleri yöneticinin önüne getirecektir.

Yöneticinin iç ve dış çevreyi gözlemlemesi ve stratejik kararlar alması gerektiğinde bir insanın sınırları ile başarılı olamayacak şekilde yakın ulusal ve küresel çevreyi işletmeyi ilgilendirdiği kadarıyla gözlemleyip özetleyip şema haline getirerek yönetime farklı kararlar almasında destek olacaktır.

Bu sayılanlar yöneticinin verimliliğini arttırabilecek olasılıklardan sadece bir kısmıdır. Sadece sayılanlar yapay zeka kullanmayan işletmelerden daha öne geçme fırsatı yaratabilir. Yapay zekanın, endüstri 4.0 ile paralel gelişecek bir konu olduğu, diğer taraftan endüstri 4.0 konusunda gelişim düzeyinin yapay zekanın başarısında etkili olabileceği de tahmin edilebilir.

Tüm bunların yanında yapay zekanın henüz aşılamayan cevaplandırılamayan soruları ve tartışma konuları olduğu da belirtilmelidir.

Öncelikle yapay zeka bir kerede çok çalışarak elde edilip her tür işletmeye de kolaylıkla uygulanabilecek bir çözüm yolu değildir. Bu durum her sektör ve alt sektörler için işletmelerin tüm büyüklük türleri için ayrı ayrı geliştirilebilecek bir kavramdır. Her işletmenin kendine uygun yapay zekayı geliştirme, deneyimlerine deneyim katarak var olan verilerden henüz var olmayan çıarımlar yapabilecek hale gelmesini sağlayacak girişimleri uzun zaman alacaktır ve stratejik düşünme yönünden güçlü uzun vadeli düşünebilen işletmeler buna öncü olabileceklerdir. Bu durum zaman, para ve enerji harcamayı gerektirmektedir.

Yine bununla birlikte işletme ve çevresi sürekli değişim halindedir. Bu yüzden yapay zekanın elde ettiği bilgiler ve deneyimler bir bölümüyle geçmişte kalabilecek, hızla değişime ayak uydurmak için yöneticinin kararlarına ihtiyaç duyabilecektir.

Yapay zeka sonuçta bir makine olduğu için ve verimliliğinin arttırılması beklenen kesimin insan olmasından dolayı, insanın da duygulardan arınamayacak olması, sebebiyle olaylara, işlere bir insan gözüyle bakamayabilecektir. Çünkü hiçbir insan sadece akliyla hareket edemez. Sevgi, saygı, nefret, vefakarlık, fedakarlık, üzüntü, pişmanlık, empati gibi duygular tüm insanların olduğu gibi, yöneticilerin de hayatlarında etkili olan duygulardan bir kısmıdır. Sosyal yönden de çalışanların ve yöneticilerin zayıflamasına, sosyalleşmenin azalmasına yol açabilecektir. Çok fazla makine iletişimine maruz kalmak daha sonra davranışsal sorunlara ve rahatsızlıklara yol açabilecektir. Duygu eksikliği, aşılamayacak ya da aşılması çok zor olarak görünen bir etken olarak yapay zeka ve verimlilik konusunda önemli bir yer işgal eder.

Bir diğer soru da yapay zeka, şimdiye kadar çoğunlukla mekanik alanlarla, teknik alanlarla gündeme gelmektedir. Özellikle zihinsel ve fiziksel emek yoğun işletmelerde tamamen çözüm olması zor ve zaman alacak biçiminde düşünülebilir. 
Etik sorunların da tartışılması gerektiği düşünülmektedir. Bir iş yerinde farklı sebeplerle çalışanların gözlemlenmesi ve fiziksel psikolojik rahatsızlıklarının ve duygularının yönetici verimliliği amaçlı öğrenilmeye çalışılması etik konusunda sorun olabilecektir. Yapay zeka ile birlikte yönetici bir süre sonra kendisini gereksiz ve önemsiz hissedebilir mi? Elbette yöneticiler, işler iyi yürürken kendilerini doğal olarak gereksiz hissedebilirler. Fakat bu duygu sürekli hale geldiğinde sorun yarabilecek bir konu olarak görünmektedir.

Son olarak yapay zeka tüm alanlarda olduğu gibi yönetici verimliliği alanında da umut verebilecek bir kavramdır. Fakat tüm sorunlara çözüm olamayacak olması ve aşılması gereken tartışılması gereken konuların da var olduğu bir alandır denilebilir. Bununla birlikte, yapay zekanın gelişiminin tahmin edilmesinin zor olduğu, yaşanıp görülecek bir kavram olduğu belirtilmelidir.

\section{KAYNAKÇA}

Çakıt E., Aylin, A. D. E. M., ve Dağdeviren, M. (2020). Endüstri 4.0 Ergonomi İçin Tehdit mi Fırsat $\mathrm{m}$ ? Verimlilik Dergisi, 3, 43-57.

Gülşen, İ. (2019). İşletmelerde yapay zekâ uygulamaları ve faydaları: Perakende sektöründe bir derleme. Tüketici ve Tüketim Araştırmaları Dergisi, 11(2), 407-436.

Gür, Y. E., Ayden, C. ve Yücel, A. (2019). Yapay Zekâ Alanındaki Gelişmelerin İnsan Kaynakları Yönetimine Etkisi. Fırat Üniversitesi Uluslararası İktisadi ve İdari Bilimler Dergisi, 3 (2), 137-158.

Howard, J. (2019). Artificial intelligence: Implications for the future of work. American Journal of Industrial Medicine, 62(11), 917-926.

Karaoğlan, A. D. (2006). Üst düzey yöneticilerin zaman yönetimi (Yüksek Lisans Tezi), Balıkesir Üniversitesi Fen Bilimleri Enstitüsü.

Kayar, M., (2012). Production and Productivity - Basic Principles and Application. Bursa: Ekin Yayınevi.

Köken, E. (2021). Yapay Zekânın Cezai Sorumluluğu. Türkiye Adalet Akademisi Dergisi, 47, 247286.

Köroğlu, Y. (2017). Yapay Zeka'nın Teorik ve Pratik Sınırları. İstanbul: Boğaziçi Üniversitesi Yayınevi.

Möslein, F. ve Bora Çınar, S. (2021). Yönetim Kurulu Toplantı Odasındaki Robotlar: Yapay Zeka ve Şirketler Hukuku. İstanbul Hukuk Mecmuası, 79(2), 699-728.

Öztürk D., G. (2019). Yapay Zekanın Etik Gerçekliği, Ankara Uluslararası Sosyal Bilimler Dergisi, 2 (4), 47-59.

Pomerol, J. C. (1997). Artificial intelligence and human decision making. European Journal of Operational Research, 99(1), 3-25.

Sarı, O. (2020). Yapay Zekanın Sebep Olduğu Zararlardan Doğan Sorumluluk. Türkiye Barolar Birliği Dergisi, 147, 251-312.

Ulusal Yapay Zekâ Stratejisi 2021-2025, https://cbddo.gov.tr/SharedFolderServer/Genel/File/TRUlusalYZStratejisi2021-2025.pdf Erişim: 22.10.2021

Ünal, A. ve Kılınç, İ. (2020). Yapay Zekâ İşletme Yönetimi İlişkisi Üzerine Bir Değerlendirme. Yönetim Bilişim Sistemleri Dergisi, 6(1), 51-78. 
Yükçü, S. ve Atağan, G. (2009). Etkinlik, Etkililik ve Verimlilik Kavramlarının Yarattığı Karışıklık. Atatürk Üniversitesi İktisadi ve İdari Bilimler Dergisi, 23(4), 1-13. 